\title{
Development of teaching material using an Android
}

\section{Ansari S. Ahmar \& Abdul Rahman}

Universitas Negeri Makassar

Makassar, Indonesia

\begin{abstract}
The purpose of this study was to develop Android-based teaching materials, which have qualities (valid, practical and effective) that can help to improve the quality of student learning outcomes and to motivate students to learn. The process of developing this material used the Plomp development model, which consists of a preliminary investigation phase, a design phase, a realisation/construction phase, a test, evaluation and revision phase and an implementation phase. To assess the quality of the learning device, the validity of the validator of experts was, then, tested in order to ensure that the teaching material is valid, practical and effective.
\end{abstract}

Keywords: Valid, practical, effective, teaching material, Android

\section{INTRODUCTION}

There are many modern tools that can be used to overcome human problems. This period is an era of science and technology. The ins and outs of human life certainly cannot be separated from science and technology. One of the foundations that support the development of science and technology as it is today is mathematics. Sudrajat said that the rapid development of science and technology has occurred with the support of mathematics [1].

The cornerstone of the support is due to the strength of the structure of mathematics and its reasoning. Students learning mathematics need many adaptations before mastering an advance cognitive skill [2]. Learning styles affect the students' learning process, so that these can be taken into consideration when designing those learning processes [3]. The development of mathematics is often used for pioneering new application possibilities in various other fields.

The development of science and technology affects the way teenagers view using the Internet as a primary goal. This development is also changing the paradigm of learning in education. On its Web site, UNESCO has said that information and communication technology (ICT) can contribute to the freedom of access to education, equality in education, delivery of quality learning and teaching, professional development of teachers and education management that is more efficient in its governance and administration [4].

Based on the results of a survey conducted by UNICEF, the Ministry of Communications and Information Technology of Indonesia and Harvard University, the US report Security Using Digital Media in Children and Adolescents in Indonesia noted that the number of Internet users in Indonesia (including children and teenagers) is predicted to reach 30 million or about $40 \%$ of the population of Indonesia. This study explored the on-line activity of a sample of children and teenagers, involving 400 respondents aged 10 to 19 years from all over Indonesia and representing both urban and rural areas. As many as $98 \%$ of children and teenagers claimed to know about the Internet and $79.5 \%$ reported being Internet users [5].

Sirozi indicated that according to UNESCO, educational institutions are not only required to encourage learners to learn, but also claimed to be able to encourage learners to learn, to acquire knowledge, to promote learning to act, to learn to live together and to learn for life (the life-long learning paradigm) [6]. Furthermore, Graf et al said that it is well known that science is quite difficult and time consuming, while it will undoubtedly be the most interesting subject for students, 
and particularly for older students [7]. Therefore, teachers need to be committed to professional development in order to take advantage of these new opportunities, and they need to renew the pedagogical view of science education.

Further, Sahid pointed out that the presence and advancement of ICT today has provided opportunities and expansion of interaction between professors/teachers/experts and learners, among learners, between learners and learning resources, and this can occur anytime and anywhere without being limited by space and time [8]. With ICT, the process of delivering and presenting learning materials and ideas can be more interesting and fun. The presence of ICT as new technologies provides a challenge to the faculty and teachers to be able to master it, so that they can choose and utilise ICT effectively and efficiently in the management of the learning process.

In recent years, there has been intense pressure (from both inside and outside the school) to take advantage of ICT in the classroom, in terms of both content and method. Over time, the push towards computer innovation has had a substantial purpose: 1) to develop new capabilities in the students, allowing their integration into a society that has been modified drastically by information technology; and 2) using computer-linked content and tools to transform and improve teaching and learning processes in the framework of the traditional curriculum [9].

IT has a major role in the world of education and this is well done in lectures. However, there are many universities in Indonesia, which have not yet introduced lecture-based IT. This fact is what prompted the authors to develop IT-based teaching materials in order to improve the quality of the learning of mathematics.

\section{METHODS}

This type of research is the development of research, known as research and development (R\&D). The development of learning tools in this study was developed by adapting Plomp's model development from 1997 [10]. The aim of this study was to develop Android-based teaching materials with qualities (valid, practical and effective) that could improve the quality of learning mathematics. The teaching materials developed were Android-based. These Android-based teaching materials were created using Intel SDK software. The model development of Plomp [10] is shown in Figure 1.

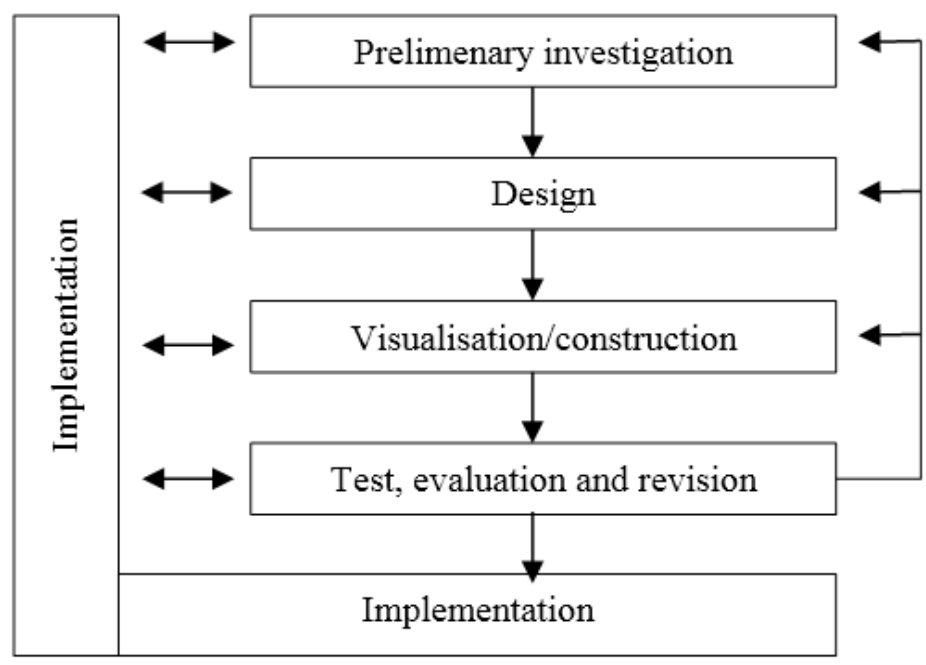

Figure 1: General model of problem-solving in education.

Note :

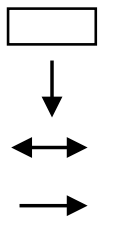

Development activity.

Flow of development phase.

Reciprocal activity between development and implementation phase.

Ongoing learning model.

Cycle of development activity.

The development of these materials follows the phases developed by Plomp [10]. Details of the activities in each phase of the development are described as follows.

- $\quad$ Preliminary investigation phase:

In this phase, the theories regarding IT-based learning as a reference in developing teaching materials and establishment of basic competencies that must be achieved are identified and studied. 
- $\quad$ Design phase:

After the preliminary investigation phase has been carried out, next is the design phase. In this phase, the principal thing is to design the instrument teaching materials, and also to determine the validity and effectiveness of the teaching materials.

- $\quad$ Realisation/construction phase:

In this phase, Prototype I of the teaching materials is compiled, ahead of the process of testing, evaluation and revision during the next development stage.

- $\quad$ Test, evaluation and revision phase:

In this phase, the focus of activities is on just two things: the validation and testing of the teaching materials. This phase aims to determine: 1) whether Prototype I of the teaching materials that have been prepared is valid or not, based on the consideration of the experts; and 2) whether the valid teaching materials can achieve results in accordance with their intended purpose. These teaching materials will be validated by two teaching material experts and one media expert.

Table 1: Category of validity [11].

\begin{tabular}{|c|c|}
\hline Criteria & Category \\
\hline $3,5 \leq \mathrm{M} \leq 4.0$ & Very valid \\
\hline $2,5 \leq \mathrm{M} \leq 3.5$ & Valid \\
\hline $1,5 \leq \mathrm{M} \leq 2.5$ & Pair valid \\
\hline $\mathrm{M}<1.5$ & Not valid \\
\hline
\end{tabular}

Note: $\mathrm{M}=$ score of validity

\section{RESULTS AND DISCUSSION}

Validity

This research has resulted in Android-based teaching materials. The feasibility of teaching materials is based on the assessment of media experts and subject matter experts. Data expert assessment of the teaching materials is based on factors, such as indicators, construction, language, content, and/or illustrations contained in the instrument validation sheet teaching materials. The results of the expert assessment of the materials, can be summarised as shown in Table 2 .

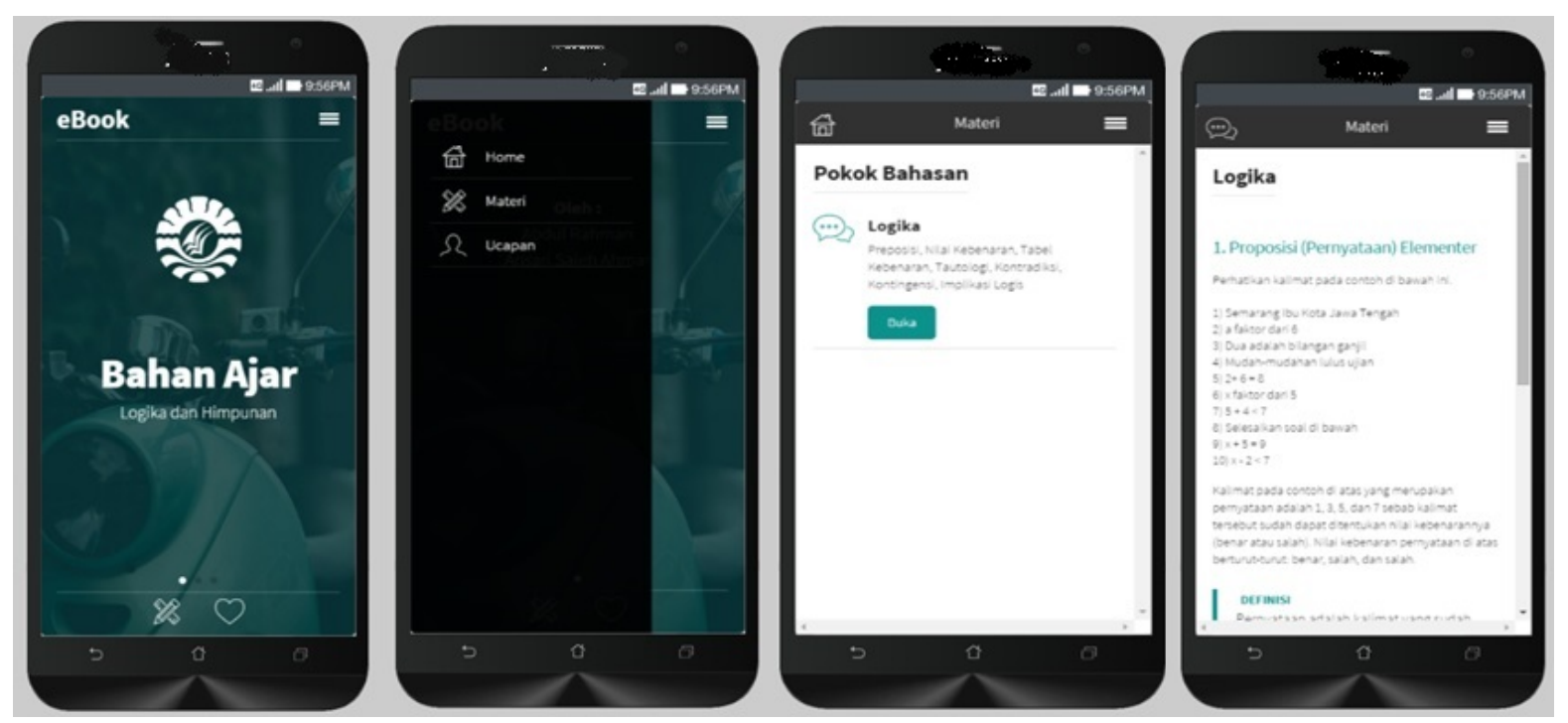

Figure 1: Display of the teaching materials in Android.

Table 2: Description of the results of expert assessment of the teaching materials.

\begin{tabular}{|l|c|}
\hline \multicolumn{1}{|c|}{ Indicator } & Mean of score \\
\hline Construction & 3.61 \\
\hline Content & 3.73 \\
\hline Language & 3.83 \\
\hline \multicolumn{1}{|c|}{ Mean } & 3.72 \\
\hline
\end{tabular}


Based on Table 2, when converted into validity categorisations, it was found that the teaching materials, in terms of the indicators are in the category of very valid, because every aspect of each type of device achieved an average value that exceeded 3.50. In addition, all validators concluded that the materials had been developed and could be used with minor revisions. In particular, there are still aspects that need to be repaired or added to, according to the advice of experts and practitioners.

\section{Responses of Students}

A student questionnaire was the instrument used to obtain data on students' responses. This questionnaire was given to students after participating in learning activities, and was to be filled in according to their feelings and what they thought of teaching materials and learning activities. The results of data analysis of students' responses in regard to the implementation of the Android-based teaching materials are summarised in Table 3.

Table 3: Students' response about the implementation of the Android-based teaching materials.

\begin{tabular}{|c|c|c|c|c|}
\hline Questions & $\begin{array}{c}\text { Strongly } \\
\text { agree }\end{array}$ & Agree & Disagree & $\begin{array}{l}\text { Strongly } \\
\text { disagree }\end{array}$ \\
\hline $\begin{array}{l}\text { I am trying to learn the Android-based teaching materials } \\
\text { at home before learning in the classroom. }\end{array}$ & 67.74 & 32.26 & 0.00 & 0.00 \\
\hline $\begin{array}{l}\text { With Android-based teaching materials, I have prior } \\
\text { knowledge before studying them in class. }\end{array}$ & 42.00 & 20.00 & 0.00 & 0.00 \\
\hline $\begin{array}{l}\text { With Android-based teaching materials, I felt better } \\
\text { prepared to face subject matter that will be delivered by } \\
\text { lecturers. }\end{array}$ & 59.68 & 40.32 & 0.00 & 0.00 \\
\hline $\begin{array}{l}\text { With Android-based teaching materials, I know the } \\
\text { sequence of the material to be delivered by lecturers. }\end{array}$ & 37.00 & 25.00 & 0.00 & 0.00 \\
\hline $\begin{array}{l}\text { Android-based teaching material given by the lecturer can } \\
\text { be used as a source of learning both in class and at home. }\end{array}$ & 64.52 & 35.48 & 0.00 & 0.00 \\
\hline $\begin{array}{l}\text { I can follow the lecturer's explanations about problem } \\
\text { solving with the help of Android-based teaching materials. }\end{array}$ & 40.00 & 22.00 & 0.00 & 0.00 \\
\hline $\begin{array}{l}\text { With Android-based teaching materials, I could } \\
\text { understand examples of problems given by the lecturer } \\
\text { faster. }\end{array}$ & 64.52 & 32.26 & 3.23 & 0.00 \\
\hline $\begin{array}{l}\text { With Android-based teaching materials, I can participate } \\
\text { actively in discussions. }\end{array}$ & 40.00 & 20.00 & 2.00 & 0.00 \\
\hline $\begin{array}{l}\text { Through the description of the materials and examples of } \\
\text { problems in the Android-based teaching materials, I felt, } \\
\text { I had insights into the advice and feedback from } \\
\text { discussions. }\end{array}$ & 67.74 & 32.26 & 0.00 & 0.00 \\
\hline $\begin{array}{l}\text { I felt the discussion groups are more warm and vibrant } \\
\text { with the help of Android-based teaching materials. }\end{array}$ & 42.00 & 20.00 & 0.00 & 0.00 \\
\hline $\begin{array}{l}\text { I felt more able to participate in class discussions after } \\
\text { doing the exercises that are on the Android-based teaching } \\
\text { material. }\end{array}$ & 70.97 & 25.81 & 3.23 & 0.00 \\
\hline $\begin{array}{l}\text { Practice questions from the Android-based teaching } \\
\text { materials helped me to understand the material that has } \\
\text { been delivered by lecturers. }\end{array}$ & 44.00 & 16.00 & 2.00 & 0.00 \\
\hline $\begin{array}{l}\text { I understand the material and practical exercises using } \\
\text { Android-based teaching materials faster. }\end{array}$ & 69.35 & 19.35 & 11.29 & 0.00 \\
\hline $\begin{array}{l}\text { What is your opinion about creation of lecture materials } \\
\text { based on this Android? }\end{array}$ & 43.00 & 12.00 & 7.00 & 0.00 \\
\hline
\end{tabular}

Table 3 shows the results of the data analysis of students' responses to the implementation of learning by using Androidbased teaching. They show that the majority of students agree or strongly agree with the use of Android-based teaching in the learning process. More than $90 \%$ of students said that they understood the material and practical exercises faster when using the Android-based teaching materials (75.81\% strongly agree and $24.19 \%$ agree) and $100 \%$ of students felt better prepared to face the subject matter.

\section{CONCLUSIONS}

The results of this study indicate that the product of teaching materials should be further developed. This is indicated by the results of expert assessment on aspects of construction, content and language, which have a mean of 3.72 for valid criteria (Table 2). Results of the student questionnaire responses in a limited test showed that on average $90.32 \%$ of students said that they feel faster and understood the materials and practical exercises when using Android-based teaching materials and $100 \%$ of students felt better prepared to face the subject matter (Table 3 ). Thus, it can be 
concluded that the teaching materials for use in the learning process and can provide students with the motivation to learn.

\section{ACKNOWLEDGEMENT}

The authors would like to thank Professor Dr Husain Syam, M.TP., Rector of Universitas Negeri Makassar and Professor Dr Jasruddin, M.Si., Director of Postgraduate Studies of Universitas Negeri Makassar for the opportunity provided to carry out this research. Their gratitude is extended to the Research Institute of Universitas Negeri Makassar for the facilitation of this research. This work was supported by funds provided by the DIPA Universitas Negeri Makassar (Grand Number: SP DIPA-042.04.2.400964/2016, 7 December 2015 and Number: 4687/UN36/LT/2016, 14 October 2016).

\section{REFERENCES}

1. Sudrajat, A., Definition of Approaches, Strategies, Methods, Techniques and Learning Model. Sinar Baru Algensindo, Bandung, Indonesia (2008).

2. Rahman, A. and Ahmar, A.S., Exploration of mathematics problem solving process based on the thinking level of students in junior high school. Inter. J. of Environmental and Science Educ., 11, 14, 7278-7285 (2016).

3. Rahman, A., Ahmar, A.S. and Rusli, The influence of cooperative learning models on learning outcomes based on students’ learning styles. World Trans. on Engng. and Technol. Educ., 14, 3, 425-430 (2016).

4. UNESCO. ICT in Education (2016). 29 August 2016, http://www.unesco.org/new/en/unesco/themes/icts/

5. Panji, A., Result of Survey of Internet Usage of Teenage in Indonesia (2014). 29 August 2016, http://tekno.kompas.com/read/2014/02/19/1623250/Hasil.Survei.Pemakaian.Internet.Remaja.Indonesia

6. Sirozi, M., Role and Benefits of ICT in Education (2013), 29 August 2016, http://www.radenfatah.ac.id/ downlot_jurnal.php?file=Peran\%20TIK\%20dalam\%20Pendidikan.pdf

7. Graf, S., Ruedal, A., Welzel-Breuer, M., Nagel, C., Stadler, H., Raykova, Z., Bühler, B., Erb, R., Jurke, T., Krzywacki, H., Lavonen, J., Buty, C., Sanchez, E., Garyfallidou, D.M., Grigoropoulos, A., Ioannidis, G.S. and Tsiokanos, A., Developing an ICT-based teacher training course designed to teach the implementation of computer aided teaching techniques to teach science: the CAT European project. Proc. 2010 Inter. Conf. on Interactive Collaborative Learning, 819-825 (2010).

8. Sahid, Development of ICT-Based Learning Media (2009), 01 September 2016, http://staff.uny.ac.id/sites/default/ files/131930136/Pengembangan\%20Media\%20Pembelajaran\%20Berbasis\%20ICT.pdf

9. Bottino, R.M., The evolution of ICT-based learning environments: which perspectives for the school of the future? British J. of Educational Technol., 35, 553-567 (2004).

10. Plomp, T., Educational and Training System Design. University of Twente Faculty of Educational Science and Technology, Netherlands (1997).

11. Nurdin, Learning Mathematics Model which Growing of Metacognitive Ability to Dominate Teaching Material. Dissertation. Postgraduate Programme, Universitas Negeri Surabaya (2007).

\section{BIOGRAPHIES}

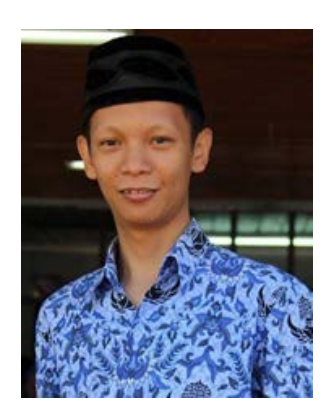

Ansari Saleh Ahmar is a lecturer in the Department of Statistics in the Faculty of Mathematics and Natural Sciences at Universitas Negeri Makassar, Indonesia. He graduated with a Bachelor's degree in mathematics at Universitas Negeri Makassar, Indonesia, in 2009. He received his Master's degree in mathematics (specifically statistics) from Universitas Gadjah Mada, Indonesia, in 2013. Besides being a lecturer, he is also an IT team member in the ICT Centre at Universitas Negeri Makassar. He has also reviewed several articles in the area of mathematics, statistics and IT.

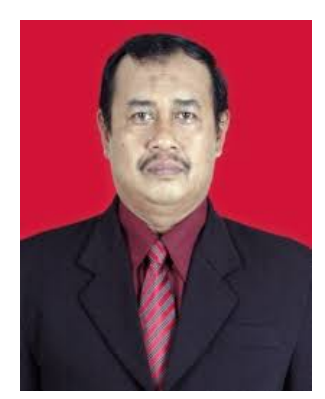

Abdul Rahman is a Professor in the Department of Mathematics in the Faculty of Mathematics and Natural Sciences at Universitas Negeri Makassar, Indonesia. He graduated witha Bachelor's degree in mathematics education at Universitas Negeri Makassar, Indonesia, in 1986. He received his Master's degree in mathematics education from Universitas Negeri Surabaya, Indonesia, in 1997 and a doctoral degree in mathematics education also from Universitas Negeri Surabaya, Indonesia, in 2006. He became Professor of Mathematics Education at Universitas Negeri Makassar in 2014. He is now Dean of the Faculty of Mathematics and Natural Sciences at Universitas Negeri Makassar, Indonesia. 